\section{Factors Affecting Gerebera jamesonii Early Seedling Branching and Mortality}

\author{
Roar Moe', John E, Erwin², \\ and Will Carlson
}

Additional index words. flower bud abortion, ethylene, irradiance, germination, water logging

Summary. The role of irradiance and/or ethylene in inducing mortality and self-branching disorders in Gerbera jamesonii Bolus. seedlings was studied. Seedling mortality increased from $8 \%$ to $57 \%$ when seed was covered with vermiculite than left uncovered during germination. Supplemental lighting for 30 days after germination decreased seedling mortality and decreased the time to visible bud compared to seed germinated under natural light only. In subsequent experiments, seeds were germinated and then seedlings were water logged or sprayed with ethephon $(0.69,3.45$, or $17.25 \mathrm{~mm})$ at four different stages of seedling development. Half of the ethephontreated seedlings were sprayed with silver thiosulfate (STS). Seedling mortality was greatest after cotyledon expansion but before expansion of the first tree leaf. The highest ethephon concentration caused reduced seedling dry weight after 42 days. Applying STS did not overcome self-branching or meristem necrosis.

\footnotetext{
${ }^{1}$ Current address: Department of Horticulture, Agriculture University of Norway, N-1432 AS-NLH.

${ }^{2}$ Department of Horticultural Science, University of Minnesota, 1970 Folwell Ave., St. Paul, Minnesota 55108.

${ }^{3}$ Department of Horticulture, Michigan State University, East Lansing, Michigan 48824.

We express our gratitude to Sakata Seed Co. and the National Research Council of Norway for their support of this project. We express our gratitude to the Minnesota and Michigan State Agriculture Experiment Stations, the Minnesota Extension Service, and growers supportive of Univ. of Minnesota and Michigan State Univ. research. The cost of publishing this paper was defrayed in part by the payment of page charges. Under postal regulations, this paper therefore must be hereby marked advertisement solely to indicate this fact.
}

$\mathrm{G}$ erbera traditionally have been propagated vegetatively due to difficulties caused by poor uniformity of seed germination and seedling growth (Cockshull, 1985; Tjia, 1984). Gerbera grow sympodially; the apical meristem initiates an inflorescence, as does the uppermost axillary meristem shortly thereafter. The next uppermost axillary meristem then maintains the growth of the main shoot axis by producing a few leaves and short internodes before it too initiates an inflorescence, and the pattern is repeated (Leffring, 1973). In seedlings, the number of leaves formed on the primary axis before the initiation of the first inflorescence varies from 7 to 26 (Leffring, 1979). The length of the juvenile phase, or the number of leaves below the first flower, varies with seasonal differences in the environment, cultivar, and growing technique.

Two problems or disorders in Gerbera production were addressed in this study: 1) high seedling mortality early in seedling development and 2) the occurrence of self-branching young plants forming many lateral shoots early in development. Flowering is delayed significantly on self-branching plants. The loss of seedlings during the early phases of seed germination and development can be as great as $50 \%$. The following hypotheses were investigated.

High seedling mortality. Early seedling mortality is caused by environmental stress during germination or early seedling development, resulting from low irradiance. Gerbera reportedly have a relatively high light requirement for rapid flower initiation (Gagnon and Dansereau, 1990). It is possible that shoot-tip necrosis is related to carbohydrate depletion in the shoot tip. For instance, reproductive apex abortion of roses occurs at an early stage of shoot development when plants are grown under low irradiance and/or low temperature (Moe, 1971; Zieslin and Halevy, 1975). Placing young rose shoots in darkness, while the rest of a plant was in light, reduced $\mathrm{C}_{14}$ translocation to the shoot tip and ultimately resulted in flower-bud abortion (Mor and Halevy, 1980).

Self-branching. Formation of many lateral shoots on seedlings is caused by early terminal inflorescence or meristem necrosis resulting from stress-induced ethylene. Self-branch- ing frequently is seen in seedlings grown in plugs that are easily water logged. Waterlogging can cause a lack of oxygen in media, resulting in ethylene biosynthesis in plants (Kapuya and Hall, 1984 ). Ethylene can induce meristem or inflorescence abortion or weaken apical dominance (Zieslin et al., 1972)

\section{Materials and methods}

Gerbera seed ('Tempo Pink Shades', Sakata Seed Co., Salinas, Calif. ) were planted in a soilless medium composed of 1 sphagnum peat : 1 perlite : 1 vermiculite (Baccto Professional Planting Mix, Michigan Peat Co., Houston) in plastic trays composed of 12 cells. Two seeds were sown per cell. Sown seed was placed in a $23 \pm 2 \mathrm{C}$ glasshouse under natural daylight conditions during December to March (1989-90) in East Lansing, Mich. If not otherwise stated, seeds were covered with a thin layer $(<2$ $\mathrm{mm}$ ) of fine vermiculite, transparent plastic film, and shade cloth $(50 \%$ irradiance reduction). Seedlings were grown in a glasshouse maintained at $21 \pm 2 \mathrm{C}$ following germination. The most-vigorous seedling per cell was selected 5 days after germination, i.e., the least-vigorous seedling was removed. Therefore, there were 12 seedlings in each 12-cell pack for each treatment. Treatments were replicated three times over time.

Effect of ethylene on early seedling development. Seedlings at four stages of development were either water logged for 12 or $96 \mathrm{~h}$ or sprayed with ethephon (2-chloroethyl phos-phonic acid) at concentrations of $0.69,3.45$, or $17.25 \mathrm{~mm}$ to study the effect of ethylene on self-branching of Gerbera seedlings. Water logging was achieved by placing the tray in $1 \mathrm{~cm}$ of water. Cell depth was $1.5 \mathrm{~cm}$. Water was refilled as needed to maintain the $1-\mathrm{cm}$ water level. Seedling stages were defined as stage $1=$ cotyledons only, stage $2=$ cotyledons plus one leaf, stage $3=$ cotyledons plus three leaves, and stage $4=$ cotyledons plus five leaves. One-half of the plants in each experiment was pretreated with 0.5 mM silver thiosulfate (STS), which blocks ethylene action in plants (Beyer, 1976). Control plants were sprayed with distilled water only. Data were collected on seedling mortality, selfbranching, and dry weight 65 days after sowing. 
Table 1. Effects of 2-chloroethylene phosphonic acid (ethepbon) and 50 m silver thiosulfate (STS) treatments at four different seedling stages ofGerbera jamesonii 'Tempo Pink Shades' on seedling mortality, incidence of self branching, and seedling dry weight 65 days after sowing. Means are presented. Interactions were not significant.

\begin{tabular}{|c|c|c|c|c|c|c|}
\hline \multirow[b]{2}{*}{ Treatment } & \multicolumn{2}{|c|}{$\begin{array}{c}\text { Mortality } \\
(\%)\end{array}$} & \multicolumn{2}{|c|}{$\begin{array}{c}\text { Self-branching } \\
(\%)\end{array}$} & \multicolumn{2}{|c|}{$\begin{array}{c}\text { Dry wt } \\
\text { (mg/seedling) }\end{array}$} \\
\hline & -STS & + +STS & -STS & + +STS & -STS & + STS \\
\hline \multicolumn{7}{|c|}{ Ethephon ( $m M$ ) (across seedling stage) } \\
\hline 0 & $11 a^{z}$ & $9 a$ & $8 \mathrm{a}$ & $11 \mathrm{a}$ & $75 a$ & $67 \mathrm{a}$ \\
\hline 0.7 & 13 a & $32 \mathrm{a}$ & $16 a$ & $9 \mathrm{a}$ & $70 a$ & $68 \mathrm{a}$ \\
\hline 3.5 & $15 \mathrm{a}$ & $24 \mathrm{a}$ & 13 a & $11 \mathrm{a}$ & $71 \mathrm{a}$ & $65 \mathrm{ab}$ \\
\hline 17.2 & $45 \mathrm{~b}$ & $38 \mathrm{~b}$ & $20 \mathrm{~b}$ & $18 \mathrm{~b}$ & $46 \mathrm{~b}$ & $63 \mathrm{~b}$ \\
\hline \multicolumn{7}{|c|}{ Seedling stage (across ethephon treatments) } \\
\hline 1 & 35 a & $38 \mathrm{a}$ & $19 \mathrm{a}$ & $7 \mathrm{a}$ & $50 a$ & 43 a \\
\hline 2 & $18 \mathrm{~b}$ & $24 \mathrm{~b}$ & $16 \mathrm{a}$ & 8 a & $63 \mathrm{~b}$ & $63 \dot{b}$ \\
\hline 3 & $16 \mathrm{~b}$ & $22 \mathrm{~b}$ & $19 \mathrm{a}$ & $14 \mathrm{a}$ & $79 \mathrm{~b}$ & $72 b$ \\
\hline 4 & $16 \mathrm{~b}$ & $11 \mathrm{~b}$ & $14 \mathrm{a}$ & $13 \mathrm{a}$ & $70 \mathrm{~b}$ & $34 \mathrm{a}$ \\
\hline
\end{tabular}

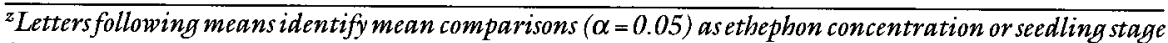
increase.
Effect of irradiance on early seedling development. Effect of irradiance on seed germination and early seedling development was studied. Gerbera seeds (960) were sown on 5 Jan. 1990. One-half of the sown seeds was covered with 4 to $5 \mathrm{~mm}$ of line vermiculite. Dead-dying (mortality), selfbranching, and normal seedlings were counted after 42 days.

Seventy-two seedlings were selected at seedling stage 2 (one true leaf $>2 \mathrm{~cm}$ in length) for an experiment to determine the effect of supplemental lighting on seedling development. Seedlings were grown under either 1) natural daylight plus continuous lighting $\left(200 \mu \mathrm{mol} \cdot \mathrm{m}^{-2} \cdot \mathrm{s}^{-1}\right)$ delivered with high-pressure sodium lamps, or 2) natural daylight plus continuous incandescent lighting $\left(2.5 \mu \mathrm{mol} \cdot \mathrm{m}^{-2} \cdot \mathrm{s}^{-1}\right)$ to control for photoperiod effects. Destructive seedling harvest data were collected 42 days after sowing on half the population. The remainder of the seedlings were further grown to determine the time from germination to visible bud. Visible bud was defined as that time when a bud $(5 \mathrm{~mm})$ could be easily seen without removal of leaves.

Experiments were organized in a torial treatment arrangement. Data were analyzed using analysis of variance procedure. Percentage data were arcsin-transformed before analysis of variance. Mean separation was conducted using Tukey's test for mean separation (Snedecor and Cochran, 1967). Determinations of significance throughout statistical analysis were determined using $\alpha=0.05$. completely random design with a fac-

\section{Results and discussion}

Effect of water logging, ethephon, and STS. Water logging had no effect on seedling self-branching, mortality, or subsequent growth (data not presented). Percentage mortality and self-branching both averaged $15 \%$ across all treatments. Although Lachover (1973) claimed that soil aeration is critical for successful Gerbera production, 4 days of water logging did not affect growth. Differences between the results of this experiment and those of Lachover (1973) could be reconciled in this experiment if water-logging duration was too short or if the soilless medium drained more rapidly than the medium used by Lachover (1973) (a mixture of composted rhizomes and roots of Glycyrrhiza glabra and and tuff).

Applying low or medium rates of ethephon did not affect seedling development (Table 1). In contrast, applying $17.25 \mathrm{~mm}$ ethephon (highest rate ) resulted in higher seedling mor- tality and self-branching and lower seedling dry weight (Table 1).

Terminal flower bud abortion is promoted by exposure to ethylene on many plants. (de Munk, 1973; Moe, 1971; Zieslin and Halevy, 1975 ), however, Gerbera seedling self-branching and early mortality do not seem to be directly attributable to the presence of ethylene, because STS did not prevent ethephon-induced seedling mortality, self-branching, or reduced seedling dry weight (Table 1). Although high concentrations of ethephon results in lower seedling dry weight and higher mortality, high ethephon concentrations (similar to that used here) can yield lower dry weight gains (Norberg et al., 1988) and are probably the basis for the low seedling dry weight and high mortality observed here (Table 1).

Effect of irradiance. Covering seed resulted in higher seedling mortality (Table 2). Covered and noncovered seed exhibited $43 \%$ and $92 \%$ seedling survival, respectively. High seedling mortality of covered seed appeared to be related to early meristem necrosis resulting in stunted cotyledon development. These results suggest that Gerbera seed may be sensitive to covering and/or lowered irradiance resulting from covering. Heavy (4 to $5 \mathrm{~mm}$ ) vermiculite covering excludes light from the apex of the seedlings early in development and, therefore, is not recommended. Reportedly, light has a promotive effect on translocation of assimilates to vegetative (Thrower, 1964) and reproductive sinks (Mor and Halevy, 1980). Mor and Halevy (1980) concluded that covering young shoot tips reduced carbohydrate translocation to the shoot tip, thus promoting tip and/ or bud atrophy.

Supplementary lighting with highpressure sodium lamps resulted in
Table 2. Effects of natural daylight (ND) plus continuous supplementary lighting with highpresssure sodium lamps $\left(200 \mu \mathrm{mol} \cdot \mathrm{s}^{-1} \cdot \mathrm{m}^{-2}\right)$ or incandescent lamps $\left(2 \mu \mathrm{mol} \cdot \mathrm{s}^{-1} \cdot \mathrm{m}^{-2}\right)$ on Gerbera jamesonii 'Tempo Pink Shades' on seedling leaf number, seedling dry weight, days to visible bud, and percent seedling mortality after 42 days. Percentage data were arcsine-transformed before statistical analysis.

\begin{tabular}{lcc}
\hline Variable & $\mathrm{ND}+2 \mu \mathrm{mol} \cdot \mathrm{s}^{-1} \cdot \mathrm{m}^{-2}$ & $\mathrm{ND}+200 \mu \mathrm{mol} \cdot \mathrm{s}^{-1} \cdot \mathrm{m}^{-2}$ \\
\hline Leaf no. & $4.0 \mathrm{a}^{\mathrm{z}}$ & $4.9 \mathrm{~b}$ \\
Seedling dry weight $(\mathrm{mg})$ & $45 \mathrm{a}$ & $125 \mathrm{~b}$ \\
Days to visible bud & $134 \mathrm{a}$ & $113 \mathrm{~b}$ \\
Mortality (\%) & $24 \mathrm{a}$ & $0 \mathrm{~b}$
\end{tabular}

${ }^{\bar{z}}$ Letters denote significant differences between means as identified by Tukey's test for mean comparisons (Snedecor and Cochran, 1967). 
greater Gerbera growth (leaf number and dry weight) and lower seedling mortality compared to seedlings grown under natural irradiance conditions only, and a shorter time from sowing to visible bud (Table 2).

\section{Conclusions}

Gerbera seedlings were not sensitive to short-term water logging in a soilless medium. High seedling mortality and/or self-branching was not induced by low rates of ethephon application. Gerbera seed should not be covered during germination, because exposure of the seedling apex to light is critical for normal seedling germination and growth. It is evident that Gerbera requires high irradiance for normal seedling development immediately after germination; supplementary lighting during low irradiance conditions is recommended.

\section{Literature Cited}

Beyer, Jr., E.M. 1976. A potent inhibitor of ethylene action in plants. Plant Physiol. 58:268-271.
Cockshull, K.E. 1985. Gerbera, p. 43-47. In: A. Halevy (ed.). Handbook of flowering. Vol. 3. CRC Press, Boca Raton, Fla.

de Munk, W.J. 1973. Flower-bud blasting in tulips caused by ethylene. Neth. J. Plant Pathol. 79:41-53.

Gagnon, S. and B. Dansereau. 1990. Influence of light and photoperiod on growth and development of gerbera. Acta Hort. 272:145-151.

Lachover, D. 1973. Growing gerbera flowers in artificial media. World Crops 25: 1619.

Leffring, L. 1973. Flower production in Gerbera. I. Correlations between shoot, leaf, and flower formation in seedlings. Scientia Hort. 1:221-229.

Leffring, L. 1979. Plant characteristics of Gerbera in relation to flower production. Proceedings of Eucarpia meeting on carnation and Gerbera. Alassio 1978. p. 155162.

Moe, R. 1971. Factors affecting flower abortion and malformation in roses. Physiol. Plant. 24:291-300.

Mor, Y. and A.H. Halevy. 1980. Promotion of sink activity of developing rose shoots in light. Plant Physiol. 66:990995.

Mor, Y., A.H. Halevy, and D. Porath. 1980. Characterization of the light reaction in promoting the mobilizing ability of rose shoot tips. Plant Physiol. 66:996-1000.

Norberg, O.S., and S.C. Mason. 1988. Ethephon influence on harvestable yield, grain quality, and lodging of corn. Agro. J. 80:768-772.

Snedecor and Cochran. 1967. Statistical procedures. Iowa State Univ. Press., Ames.

Thrower, S.L. 1964. Translocation of labeled assimilates in the soybean. III. Translocation and other factors affecting leaf growth. Austral. J. Biol. Sci. 17:412-426.

Tjia, B. 1984. Gerbera production and its problems. Intl. Proc. Plant Prop. Soc. $34: 365-375$

Zieslin, N., A.H. Halevy, Y. Mor, A. Bachrach, and I. Sapir. 1972. Promotion of renewal canes in roses by ethephon. HortScience 7:75-76.

Zieslin, N. and A.H. Halevy. 1975. Flower bud atrophy in Baccara roses. II. The effect of environmental factors. Scientia Hort. 3:383-391. 